\title{
EDUCATIONAL ROLE OF LITERATURE IN ISLAM
}

\author{
Abdul Karim Abdullah*
}

\begin{abstract}
This paper argues that literature - story telling in particular - can be an effective way of teaching ethics. Exposing readers to good role models can help impart ethical values. The Qur'an itself uses story telling to convey many of its ethical principles. Literature can serve as a powerful instrument in the cause of civilisational renewal, not only by promoting a culture of learning and literacy, but also by contributing to the development and strengthening of moral integrity.
\end{abstract}

\section{Art, science and literature - commonalities and differences}

Literature is a collection of writing on a particular topic or in a specific area, with the purpose of conveying knowledge or insight of one kind or another to the reader. Literature is a means of communication. There is literature as art as well as literature on the subject of science. Literature as art differs from scientific literature in important ways. This is due to differences between art and science.

Science is typically classified into natural (empirical) science and social science. Natural science focuses on the world of nature. Social science, by contrast, looks at man. Religious sciences focus on the relationship between the Creator and his creation. They also help man understand his duties to the Creator as well as to fellow human beings. Religious sciences comprise the study of sacred text, beliefs, ethics, languages, interpretation, jurisprudence, and history.

Natural science seeks to comprehend, explain and to transform the world. Its aim is to make life better in the material sense. Art, by contrast, seeks to understand, explain, and reform man. In other words, art and science complement one another.

Art seeks to capture and express the sublime (the spiritual). Art in the form of literature can help a person to become a better human being by making him or her aware of his or her limitations. Exposure to a work of art opens a new world to man, one that need not exist merely in the imagination. In this sense, art can help man realise his potential to the fullest.

The power of art to educate is due to its ability to convey, in a literary manner, wisdom conveyed by religion. Unlike science, art speaks directly to the heart. By reforming individuals, art can help reform society. It can also do this by raising social awareness, for example by highlighting the plight of the poor and vulnerable minorities. 
Art can be classified into visual, performing and literary art. Visual arts comprise calligraphy, painting, and sculpture. Performing arts include music, drama, and film. Literary arts include poetry, drama, short stories and novels.

Art can also be categorised according to the period in which it flourished. Thus we speak of classical, medieval or romantic art. However, art can also be classified into Umayyad, Abbasid, Persian, and Ottoman art, each exhibiting significantly different features and characteristics of their own. ${ }^{1}$

Art and science constitute different ways of interacting with, and expressing insight about reality. The methodology for discovering knowledge in the modern sciences is encapsulated in what is known as the "scientific or empirical method." But what is the methodology of capturing and expressing insight by art?

The artist never produces art from nothing; a work of art is a product of the artist's engagement with his or her own experience of life and a response to it. In that sense, every work of art is a statement. The imagination plays an important role in art. $^{2}$ With the help of the imagination the artist can escape the narrow confines of his or her own experience.

Art aims at perfection. What is striking about works of art is that they appear to be perfect and flawless. A "masterpiece" is a work of art that is free of defects, is internally consistent, and conveys a powerful message to the reader. It leaves a lasting impression, and is both aesthetically pleasing and ethically endowed.

In general, art is intuitive while science tends to be rational. Art communicates an articulation of reality to the viewer or the reader in a different way than science. The latter observes, measures, records and analyses data; it also discovers patterns and predicts outcomes. It identifies and describes cause and effect relationships. ${ }^{3}$ It does this by studying relationships between measurable variables and discovering what are known as "scientific laws."

Science relies mainly on the intellect (reason) while art utilises intuition. However, this does not mean that science can dispense with the imagination, or that art can do without precision. It just means that precision manifests itself in a different way in the arts than it does in the sciences. In the sciences precision is a measurable phenomenon. In the arts, precision takes an intuitive form. The imagination is also important in scientific research, as it would be difficult to make scientific discoveries without the use of the imagination.

While art does not appear to have any immediate practical use, the products of science are viewed as eminently useful and practical. ${ }^{4}$ However, art need not merely entertain or please; art can also, and indeed should have a didactic or educational function. ${ }^{5}$ For example, children can learn ethics through stories, as good stories are interesting and easy to comprehend. 
At its best, art seeks to expresses truth, in particular truth about what matters most. Art alerts the reader to the need for spiritual growth, inclusive of the purification of the soul. Art teaches man that he or she can rise above the constraints and limitations imposed on him or her by the demands of a given time and place.

Art also alerts the reader to the need for ethical consciousness, or the idea that a person is responsible for his or her actions. Artistic experience alerts a person to the fact that his or her actions impact other people in different ways, that can hurt as easily as gratify.

Art, in other words, teaches man to act with justice. The ethical teaching of a story is typically summed up in the expression, "the moral of the story is ..." The core message in every good story, its "moral" constitutes its most important, educational part.

\section{Literature in culture and civilisation}

Literature as art takes the form of poetry, stories or drama. Poetry is written in verses that rhyme and generally give expression to feelings. While poetry is a part of literature, not all literature is poetry. The greater part of literature comprises inspirational works: short stories and novels.

Every nation has its own literature. The quality of its literature reflects the degree of its spiritual development. National literature consists of various narratives that express and encapsulate the unique identity of a particular community.

Literature is a response to, and a commentary on the prevailing conditions of a given historical period. Literature attempts to transcend the limitations imposed on the artist by historical circumstances. It seeks to discover and communicate the highest or universal truth.

Literary effort seeks to solve the riddle of human existence, to answer questions such as "Who am I?" "Where did I come from?" "What is the meaning of life?" It tries to do this by reconciling the temporal with the eternal, the subjective with the objective, and the particular with the all-encompassing. It can accomplish this by alerting man to his roots and helping him to understand better his place in the greater scheme of things.

It is neither possible nor desirable to separate literature from its social and historical context. In that sense, all literature is "historical." This does not mean, however, that literature cannot express what is known as "higher" or "timeless" truth, an awareness that transcends the constraints of a particular time and place.

Different types of literature achieve their objectives in different ways. Classical literature emphasises tradition, respect for elders, order, duties, and a sense balance, harmony and hierarchy. Medieval literature gave expression to religious feelings and devotion. The Romantic movement, by contrast, emphasised love, 
the family, the individual and spontaneity. These periods broadly reflect different stages in the social and moral development of man.

Literature as an art form-fiction, non-fiction or science fiction-communicates meaning to readers. "Meaning" is a specific conception of reality and of man's place in the world. This conception is shaped, to a large degree, by the artist's own experience of, and response to the conditions of his or her time.

Various articulations of meaning compete for the allegiance of man. "Meaning" as it finds its expression in literature, takes the form of a "worldview." This worldview is expressed in the way various characters relate to each other and to the environment in which they find themselves, how they struggle with, and eventually overcome or succumb to, as the case may be, the challenges that face them.

Awareness of his or her community's worldview enables a person to fit in better. The worldview of a particular community teaches him or her his duties, his place, responsibilities, what he can expect, what he must or must not do and how to conduct himself or herself in general.

Every worldview holds up some value as being the most worthy of realisation. One ideology may emphasise equality, while another may place a greater emphasis on liberty. Yet another worldview may emphasise piety as the most important quality worthy of attainment.

Despite a great diversity of ideals that one encounters within the world's leading civilisations, some values appear to be shared by all civilisations. For example, all major civilisations view justice as a universal value. Differences arise because different people tend to understand justice differently, and as a result have different notions about how to realise it.

Because of the diversity of values and the different ways of life they signify, an important challenge in life is to identify and commit oneself to a way of life that is indeed worthy of commitment. The choice is important, as man's destiny depends on the way of life he chooses to follow. Different choices or alternatives are identified and explored in all great literature.

Making the right choice requires knowledge. Knowledge not only enables man to make the right choices, but also to rise above the confines of particular historical periods in which he or she may find himself. The attainment of knowledge, however, presupposes the ability to distinguish truth from falsehood.

As there are different types of truth, there are also different types of knowledge, each kind of knowledge encapsulating a certain kind of truth. The highest truth is religious truth. Indeed, the Qur'an refers to God as the Truth (al Haqq). ${ }^{7}$ The challenge in life is to attain knowledge of the highest truth. This takes place by becoming conscious of God. Once a person attains knowledge of the highest truth, he or she is ready to receive and benefit from guidance. ${ }^{8}$ 
There are many ways to gain knowledge. The invention of the printing press and of the Internet has made possible the dissemination of knowledge on an unprecedented scale. As a result of the wide availability of information, critical thinking skills have become more important than ever before.

Readers need to assess the quality of the information now available on the Internet and elsewhere. Critical thinking is also important for literary criticism, the discipline that evaluates literary works in the light of credible criteria.

Globalisation has resulted in a major democratisation of information dissemination. This offers opportunities but also presents risks. The opportunities include the possibility of new art forms, and reaching rising numbers of people. The risk is that excellent literature may get buried under a heap of mediocre, commercial production.

Literature plays an important role in both in culture and civilisation. The difference between the literature of a culture and that of a civilisation is that the appeal of culturally determined literature tends to be limited to members of a particular ethnic class, while literature of a civilisation transcends tribal differences and speaks with universal appeal. Great literature is "borderless."

Each civilisation has its own literature. This literature expresses the identity of the civilisation and helps maintain its cohesiveness over time. In the process of interacting with its counterparts, a civilisation may incorporate ideas or knowledge from other civilisations. A degree of "cross-pollination," in other words, takes place over time. ${ }^{10}$

The books that a given civilisation cherishes tell a great deal about that civilisation. It is the responsibility of knowledgeable persons to call the attention of their fellow citizens to the best books available to them.

In one sense one may perhaps speak of "a battle of the books." At a deeper level, however, this "battle" reflects a battle of ideas and even ideologies, a competition of different worldviews for the allegiance and support of mankind.

Ideas confront each other in books, the mass media and cyberspace. They also confront one another on battlefields. Adherents of one ideology (such as socialism) may come into conflict with the supporters of another ideology (such as national socialism).

Ideas that form the core of an ideology explain to a significant degree the success or lack of it by the adherents of that ideology. Flawed ideologies and the ways of life they propagate do not last, as the fate of communism, for example, has shown.

Additional examples of conflicts fought on battlefield between different ideologies can be found in various "revolutions." These have ushered in what is known as "modernity." Modernity emerged as a result of various intellectual, political and economic developments. 
The most important among these appears to have been a re-articulation of the relationship between reason and revelation. This resulted in the elevation of human reason to a position higher than what it occupied previously and its engagement as an active participant in the quest for knowledge. These developments collectively culminated in what came to be known as the Enlightenment. ${ }^{12}$

The elevation of reason (and by implication science) and the side-lining of religion altered the relationship between the two, at least as it was commonly understood until then. Reason and science found new prestige, while religion was relegated to the realm of private pursuits.

The political upheavals that accompanied the Enlightenment include the English, American, French, and other revolutions. ${ }^{13}$ These events represented not only major transformations of a political nature; they also heralded the emergence of new notions about ethics. These notions differed in significant ways from their predecessors. ${ }^{14}$

Significant upheavals have also taken place in Muslim history. These have been marked by the disintegration of various dynasties and their replacement by others. Even in contemporary times we find various upheavals taking place in different parts of the world. Examples can be seen in the changes of various regimes that have taken place, and are still taking place, during and in the aftermath of what has come to be known as the Arab Spring.

\section{Good literature}

Good literature is enjoyable as well as educational. Such literature helps the reader to become a better person (ethical). It does this by exposing the readers to good role models, represented by leading characters within literary narratives. ${ }^{15}$ Literary narratives alert readers to the consequences of different ethical choices, as illustrated within the narrative of a story.

One example is a life of crime. A novel can show that "crime does not pay," by showing the consequences of a criminal lifestyle. Literature appeals to fitrah or human nature. It is only natural to be interested in stories. Human nature (fitrah) is such that the human being responds to, and is moved by stories.

In order to be truly internalised (learned), knowledge needs to be apprehended not only intellectually but also in some sense "experienced." In Islam, sufis distinguish between mere knowledge ( $\mathrm{ilm}$ ) and a higher form of cognition in the form of the experience of knowledge (ma'rifa).

Literature explores various archetypes and contrasts them to each other, typically by casting them as antagonists. Good literature alerts the reader to the difference between good and evil and to draws him or her to join the struggle on the side of the good. The writer should make good characters attractive and 
worthy of emulation. Bad characters, by contrast, should be cast in a poor light, so that readers will not want to become like them. ${ }^{16}$

An important quality of good literature is realism. Writers can gain the trust of their readers by being realistic, and by writing about the concerns of the readers. Unrealistic scenarios will not likely hold the attention of readers for long.

Interest can be enhanced by the use of literary devices. These include dialogue, description, suspense, metaphors, similes, and allegories. There is a need to strike a balance in the use of literary devices, for example between description and dialogue. Stories can be told in the first person or the third person.

Literature develops compassion in a reader, a concern for the "other." Compassion is emphasised extensively in the Qur'an. Literature can help make readers more compassionate by making them aware of the suffering of other people. By calling the reader's attention to the plight of the poor, literature can also help readers develop social consciousness, and in that way contribute to social change. In other words, literature serves not only as a mirror to reflect social conditions, but also as a catalyst to change them. ${ }^{17}$

Good literature should illustrate the triumph of good over evil. ${ }^{18}$ By alerting the reader to the need be ethical, good literature can strengthen the reader's morale. The role of the writer is to serve as the "conscience" of his or her community. By writing, he credits acts of goodness and censures acts of wickedness. In this way he or she can contribute to "commanding what is good and prohibiting what is evil."

\section{Literature and religion}

There is on-going debate about literature and the role it can play - if any - in the lives of Muslims. Strict interpretations of Islam appear to limit the role of literature (and art) in Islam. Artistic representations are often identified with vain indulgence and thus discouraged.

Some critics view literature with apprehension, as undesirable and even harmful; it may keep people from more important commitments. Others including non-Muslims - perceive literature as "dangerous." The danger stems from "corrupting" the morals of the people and thereby contributing to the disintegration of the community.

Concerns about possible harmful effects of literature on readers are justified. Indeed, such concerns have been around for as long as literature. Many stories, novels and plays portray questionable behaviour. Some works even appear to justify such behaviour by making it appear "normal." Positive role models are often lacking. In so far as no element of worship is involved, however, writing and reading literature are not incompatible with an Islamic outlook.

Even the Qur'an directs the believers not to 'follow' the poets (26:224), for they often say what they do not do. However, the text here does not say 
anything negative about poetry as such. Rather, it touches on what the poets do or believe. A lesson to draw here is that the poets should infuse realism and ethics into the fabric of their poetry. So if poets write poems that promote right values and causes, there should be no basis for objections from the perspective of Islam.

The fact that storytelling is in principle not objectionable in Islam is confirmed by the fact that the Qur'an itself narrates many stories (qasas). It does this with an educational purpose in mind. Where writers of stories follow the Qur'anic model - and seek to educate - literature in principle would be acceptable in Islam, as it helps to realise the aims of Islam. Qur'anic messages often need to be delivered in lighter language for children, the youth, and those lacking direct familiarity with the Qur'an. In this way, literary effort can contribute to a re-invigoration of the Islamic civilisation. ${ }^{19}$

Literature can also help build bridges of understanding between different civilisations. Such literature enables the reader to see things form other people's perspectives, by "putting the reader in other people's shoes," and serve as a means of promoting good relations and friendship among people.

It is best to focus on books that have emerged over time as "classics." These can be found in every civilisation. These books have attained the status of "classics" by articulating the basic human choices (the human condition) in ways that people from different backgrounds can relate to easily. Indeed, many classics have drawn inspiration from religion.

The study of literature needs to be accompanied by learning how to analyse literature, an activity known as literary criticism. In the case of Islamic literary criticism, the reader is taught to read and comment on literature from the Islamic perspective. In this way, any weaknesses of the work, such as the absence of noble and admirable characters, can be highlighted. In a similar vein, the merits of a give work can be pointed out, where and when appropriate.

There is no prohibition of telling of stories in the Qur'an. The Shariah upholds the principle of original permissibility (ibahah): everything is permitted unless it is prohibited by a clear text. Literary merit should be measured by its content and message. Whether it serves a good or a bad purpose is the decisive criterion from the perspective of Islam.

\section{Literature and the Qur'an}

The Qur'an is eminently well suited to provide guidance to writers, as it is in itself, a masterpiece of communication. This is attested to by the Qur'an itself, especially in those of its verses which call attention to its own inimitability $\left(i^{\prime} j a z\right) .{ }^{20} I^{\prime} j a z$ is manifested not only in the linguistic excellence of the Qur'an but also in the overall psychological effect that it generates on the part of the reader. 
The language, rhythm, message, narrative, emotional appeal and psychological impact of the Qur'an all combined become the embodiment of $i$ 'jaz.

By common acknowledgment, the Qur'an had a major impact on the development of Arabic literature. The Qur'an is rich in the use of literary devices, use of illustrations, imagery, and metaphor, thus adding beauty, life, and colour to plain words. ${ }^{21}$

The Qur'an has without doubt provided a level of linguistic excellence unparalleled in the history of the Arabic language ... The Qur'an remains a book of inimitable quality, not only from a linguistic, but also from an intellectual, point of view. ${ }^{22}$

A good example of a narrative with an ethical teaching can be found in the story of the prophet Joseph. ${ }^{23}$ This story is presented in the Qur'an as a "most beautiful story" (ahsanul qasas). As a young man, Joseph was betrayed by his own siblings, who were jealous of the apparent preference given to him by their father, the prophet Jacob, son of Isaac, one of the two sons of Abraham.

Out of jealousy, Joseph's brothers conspired against him - initially even considering killing him - and dropped him into a well. The story illustrates the trials and tribulations that may be experienced by a person over the course of his or her lifetime. However, patience, perseverance and above all faith in God will carry a person through, God-willing.

Joseph was eventually rescued by travellers and sold into slavery in Egypt for a "small price." The wife of his master tried to seduce him but Joseph did not go along. She falsely accused him and he was imprisoned. However, on account of his ability to interpret the King's dream about the coming famine, he was eventually released from prison. He then became a very important person in Egypt, the keeper of the storehouse.

Later his siblings came to Egypt for the purpose of trading. They did not recognise him but he recognised them. He arranged for his father to be brought into Egypt also. The story has a happy ending, where the family is re-united and settles in Egypt.

The story explores a number of themes. Among them are sibling rivalry, conspiracy, betrayal, suffering, exile, slavery, false accusation, need for patience, redemption, clearing from false accusation and finally reconciliation.

The story illustrates that no matter how badly things may look for a person, one should never give up hope and put one's trust in God. It also illustrates that God "is the best of planners." 24

On account of its universal appeal, Leo Tolstoy in What is Art identified the story of Joseph as one of the most universal of stories. ${ }^{25}$ Thomas Mann wrote an entire book, Joseph and his Brothers, after having been inspired by it. ${ }^{26}$ The 
story of Joseph thus constitutes an excellent example of a story with a powerful message, which can serve as a model for all writers.

\section{Literature in the Muslim world}

The Islamic civilisation produced a notable literary legacy, which includes the works of Hafez, Rumi, Iqbal, Naguib Mahfouz and others. ${ }^{27}$ The origin of Arabic poetry goes back about sixteen centuries. It emerged within the context of a tribal culture, and initially took the form of oral recitations. Literature in written form did not emerge until after the revelation of the Qur'an. ${ }^{28}$

Poets were important persons in the tribe. Poets provided their tribes with narratives that expressed the identity and aspirations of the tribe. The poet was an important spokesperson for the tribe. Central to his work was the expression of tribal solidarity or asabiyyah. ${ }^{29}$

Poetry was also the primary means of education in good manners ( $a d a b)$. Poets extolled the virtues of the Arab tribes and motivated them in battles by emphasising the strength of one's own tribe and highlighting the weaknesses of the opposing tribes. Poems depicted in detail various heroic exploits and adventures by brave warriors. The theme of love also figured prominently in the literature of the Arabs.

Well-known stories include The Thousand and One Arabian Nights or the exploits of Sindbad the Sailor..$^{30}$ The hakawati (storyteller) played a major role in the Arab community right up to the advent of the mass media.

The revelation of the Qur'an transformed the Arab society and its way of life in a profound way. It weakened tribal loyalties, and in their place introduced the universal, civilisational outlook of Islam. It brought focus on ethical concerns and weaved them into the fabric of Arabic literature.

Gradually, the poet gave way to the imam, and the recitations of poetry gave way to recitations of the Qur'an. The praise of the tribe gave way to the praise of God. In this way the Qur'anic revelation transformed a tribal culture into a universal community of believers.

Under the banner of Islam, the warring Arab tribes united into a single nation. Later, other nations were drawn in to form a civilisation, in which tribal or ethnic differences gave way to a faith-based community. ${ }^{31}$

Islam also had a significant impact in Persia. Under the influence of Sufi teachings, mysticism became a significant element of Persian poetry. This poetry had a robust didactic component: many poems conveyed wisdom to readers. Nowhere was the influence of Islam on Persian literature more evident than in the work of Jalal al-Din Rumi, in particular his Masnavi. ${ }^{32}$

Rumi lived during the time of the sacking of Baghdad by the Mongols in 1258. The Masnavi comprises 26,000 verses. Persian sufis regard it as second 
only to the Qur'an as a source of enlightenment and mystical experience. The Masnavi is a story of a "spiritual hero in quest of the Fountain of Life." 33

Rumi's work influenced various sufi orders in Persia, Turkey and India. Another example of Persian poetry may be found in the work of Mohammad Shams al-Din Hafez. He lived in Shiraz and was a master of the ghazal. ${ }^{34}$ His collection (divan) contains 400 ghazals. ${ }^{35}$

The origins of Turkish literature date back to the time of the Mongol occupation of Anatolia, at the end of the thirteenth century. As in Persia, Turkish poetry was likewise influenced by mysticism. The fourteenth century saw a blossoming of Turkish literature. A well known poet of this era was Asik Pasa. His Book of the Stranger was a didactic poem exploring ethical and moral themes.

A popular type of poem was the heroic epic. The oldest example of this kind of poem is The Book of My Grandfather Korkut, known in English as The Book of Dede Korkut. It contains twelve tales, recounting the exploits of various Oghuz heroes. ${ }^{36}$

The novel did not emerge in Turkish literature until the end of the nineteenth century, notably in the works of Ahmet Mithat, published from 1875 to 1910. Under the influence of Mithat, both poetry and prose took on a distinctly didactic character, a trend that was to continue subsequently.

Naguib Mahfouz, the recipient of the Nobel prize for literature in 1988, was a noteworthy Egyptian writer of the twentieth century. His Cairo Trilogy traced the lives of three generations, headed by the patriarch el-Sayyed Ahmed Abdel Gawad, starting with World War I and ending with the overthrow of King Farouk by the Nasser regime in 1952 .

The Trilogy documents a family conflict as well as the efforts of ordinary people to adapt to modernity. He emphasised the need to think imaginatively. ${ }^{37}$ His social criticism led to the banning of some of his books.

Naguib Mahfouz called for a "new world," one in which Arabs would participate and collectively pursue scientific empowerment, economic development, and peaceful co-existence with the other ${ }^{38}$

Urdu literature found an eloquent representative in the work of Muhammad Iqbal, a well-known poet in Pakistan. On account of his participation on the Muslim independence movement, Iqbal has been hailed as a "spiritual" founder of modern Pakistan.

Iqbal's thought is rooted in the Qur'an, and shows a deep concern with reforming the education of Muslims. The Reconstruction of Religious Thought in Islam was a collection of lectures published in 1930. Here Iqbal tried to articulate the universalism of Islam that, as he saw it, was being eroded by parochial tendencies. 
Iqbal saw the purpose of life in the need to actualise one's potential to the fullest by developing the self. This was to be done by means of attaining knowledge. His theory of knowledge (epistemology) identified empiricism, rationalism, and intuition as different ways of perceiving reality, all complementing one another. ${ }^{39}$

He liked to refer to the verse in the Qur'an, which states, "Verily God will not change the condition of a people till they change what is in themselves" (Q arRa'd, 13:12). He emphasised action. He saw the best representation of the ideal person in the prophet of Islam (pbuh).

\section{Literature in the West}

Literature plays an important role in other parts of the world as well. Much of it explores the themes of social and personal reform. One example can be found in Charles Dickens' Oliver Twist, published initially in 1837. The novel is set against the Industrial Revolution. The novel depicts a life of poverty and hardship. The book exposes the harsh treatment of orphans by the Victorian society.

Oliver was an orphan who worked in a workhouse and was later employed by an undertaker. He escapes to London and is adopted by Fagin, the leader of a gang of young thieves. The book chronicles Oliver's many attempts to escape the life of crime forced on him by circumstances.

The novel is an indictment of Victorian society and its harsh exploitation of child labour. In a different way, the novel also teaches that "crime does not pay," as all evil characters come to a bad end in one way or another. ${ }^{40}$

Victor Hugo's Les Miserables was first published in 1862, twenty-five years after Dickens' Oliver Twist. It is set against a time of revolutionary transformation of France from a medieval to an industrial society. Like Dickens' novel, Les Miserables illustrates the plight and social alienation of the poor. ${ }^{41}$

The story begins just after Napoleon's second defeat at Waterloo. The main character, Jean Valjean, attempts to escape his criminal past and find a "straight path." He eventually achieves success through repentance and personal reform. ${ }^{42}$

Leo Tolstoy's Anna Karenina narrates how the main character in the novel, Anna comes to a tragic end. She followed her desire for love without regard for the consequences of her actions. As a result, she paid a heavy price. ${ }^{43}$ By contrast, two other characters in the novel, Levin and Kitty, are able to have a good marriage.

The novel explores the themes of infidelity, family break up, social isolation and personal tragedy. All these were illustrated by Anna's experience. The relationship of Levin and Kitty was balanced, and in that way it illustrated the "middle path." Theirs is the only truly happy family in the novel. 
Faust was published in 1808. Goethe worked on it for many years. It tells a story of a scholar who sells his soul to the Evil One in exchange for power and pleasure. Goethe based his work on a German legend. A Faustian person is someone who sacrifices moral principles for worldly gain. Faust's story is a tragedy.

Faust was dissatisfied with his life as a scholar. He felt something was missing from his life. He thought it was power and pleasure. With the devil's help, Faust seduced an innocent young girl, Gretchen, and destroyed her and her family. However, God forgave her and she was saved. In order to obtain his own salvation, Faust needed to go through a series of additional trials.

Dante's Divine Comedy, a masterpiece of Italian poetry, is an allegory narrated in the first person. Written between 1308 and 1321, it shows influence of Islam. Its publication in Europe signalled the end of the Middle Ages and the beginning of European modernity, in the form of the Renaissance.

The Divine Comedy describes a man's journey to God, a man who is initially lost and in search of "the straight way." This journey takes place in three stages: hell, purgatory and heaven. Each constitutes a separate part of the work. The narrative is an exploration of the "unseen" world or metaphysical reality. ${ }^{44}$ The emergence of the Renaissance during Dante's time was due in part to the rise of secularism, challenging the widespread dominance of institutionalised religion. ${ }^{45}$

\section{Conclusions and recommendations}

Literature enables readers - especially young readers - to step outside of the confines of their experience and gain a broader perspective. This helps the reader to see the "bigger picture," and hopefully develop in him or her empathy for the other. Exposure to literature can educate the reader and make him or her more tolerant of differences between people and in this way contribute to a more peaceful co-existence on the earth.

Literature offers opportunities for teaching of ethics. It gives concrete expression to abstract concepts and illustrates them in real life scenarios. These abstract concepts include what are known as virtues and vices, such as piety, fair play, gratitude, patience, generosity, and compassion.

Vices by contrast include impiety, injustice, self-centeredness, and cruelty. Literature provides readers with good role models to emulate. This learning experience takes place with the help of the imagination.

Ethically endowed narratives represent moral qualities in the form of different characters, both good and evil. The struggles between the various characters represent the struggle between good and evil. Literary narratives enable people to see the consequences of wrong choices in the lives of other people, without having to experience personally the suffering caused by those choices. In this 
way, educational literature can help people live better lives, more in harmony with the ethical teaching of religion.

Given the important role literature plays in the development of a community, it is advisable to support the writing and teaching of good (educational) literature. Institutions of learning should offer courses in creative writing, literature, comparative literature and literary criticism.

- Muslim institutions of learning appear to be slow in appreciating the literary contributions of other traditions. It is high time to change this by offering courses in Islamic and Western literature.

- Courses on Islamic literary criticism should focus on major and more mature literary traditions and disseminate the best in Arabic, Turkish, Persian, Egyptian and Urdu literature to wider levels.

- Translations of worthy literary works from other languages should be supported. This will enrich each civilisation thus benefiting from the literary masterpieces found in other civilisations.

- Competitions should be held and prizes offered for outstanding contributions. Exposure to good literature should help to develop better taste in the reader.

- Courses in comparative literature in Muslim institutions of learning should explore themes common to different traditions, with the objective of highlighting their commonalities and differences in the spirit of advancing harmony and cooperation between them. Interdisciplinary courses on literature and ethics or literature and social reform, should also be offered.

\section{Notes}

* Abdul Karim Abdullah (Leslie Terebessy), Assistant Fellow at IAIS, earned his MA in political philosophy from the University of Toronto, Canada (1999) and a MEd (1986) from the University of Toronto's Ontario Institute for Studies in Education (OISE). A former lecturer, editor, writer and coordinator of the English programme at University Sains Islam Malaysia (USIM), his current projects involve research into the current financial crisis, critical thinking in Muslim societies, and Islamic Finance. He has edited Islamic Studies at World Institutions of Higher Learning (Kuala Lumpur: USIM 2004). He can be contacted at abdulkarim@iais.org.my.

1. For an account of the spiritual origins of Islamic art, see Nasr, Seyyed Hossein Nasr, Islamic Art and Spirituality, Golgonooza Press, 1987.

2. On the importance of the imagination in literature, see Northrop Frye, The Educated Imagination, CBC Enterprises, 1963.

3. There is significant evidence in the Qur'an of the importance of cause end effect relationships in Islamic epistemology. Perhaps the most obvious of these is the link between a person's actions or "deeds" and his destiny. The believers of and 
the doers of good deeds are rewarded by God with paradise. The disbelievers and doers of evil are rewarded with hell.

4. Nasr, Seyyed Hossein "Science and Civilisation in Islam," Canadian International Youth Letter, p. 8; accessed online on 19 February 2015; <http:// www.paep.ca/en/CIYL/2004/doc/nasr_science_in_islam.pdf $>$

5. Not everyone, even among educators, is convinced that literature has a didactic role to play in education. See for example Gisele E. Magnuson in "The Round Table: Should English Teachers Be Involved in the Teaching of Values in the Classroom? If so, How?" English Journal, Vol. 76, No. 8, 1987, pp. 55-58, National Council of Teachers of English, p. 58, accessed online on 29 March 2015; <http://www.jstor.org/stable/819416>

6. The view that "there is no meaning in literature," expressed among others by Northrop Frye, is not uncommon among contemporary literary critics. See for example Frye, Northrop Creation and Recreation, University of Toronto Press, 1980 , p. 28.

7. Q an-Nur, 24:25.

8. Ashraf, Syed Ali "Islamic Principles and Methods in the Teaching of Literature," British Journal of Religious Education, Volume 1, Issue 2, p. 52, Taylor and Francis Group, Routledge, 1978, accessed online on 7 March 2015; <http:// www.tandfonline.com/doi/abs/10.1080/0141620780010204?journalCode $=$ cbre 20\#preview>

9. One indicator of "great" literature is that worthy books are often translated into other languages. This indicates the transnational appeal of such writing.

10. This "cross-pollination" is not restricted to mere ideas. Inventions also get passed on from one civilisation to another. For example, paper was invented in China. Subsequently, Muslims began to produce paper in an improved form. Finally, the Christian world discovered paper upon the re-conquest of Muslim Spain and also improved on it.

11. Some universities have implemented what they call "great books programs." These are programs in which only the best books are studied, to enable students to interact with the best thinkers of the past and present.

12. What is known as the "Scientific revolution" was triggered by the Renaissance. The Scientific revolution in turn was a precursor of the Enlightenment. It is of some interest that the Renaissance was in an important sense the exact opposite of the rejection of pre-modern ideas in the Muslim world by the opponents of the Mu'tazilites. In contrast to this rejection, the supporters of the Renaissance developed interest in these ideas, much like the Muslims themselves did earlier, during the time of Harun al Rashid and the flowering of the Muslim civilisation in Baghdad at the time.

13. These took place in 1688,1776 , and 1789 , respectively.

14. An example of such a new ethical paradigm can be seen in the rallying cry of the French revolution, "liberty, equality and fraternity."

15. Halstead, J. M. "An Islamic Concept of Education," Comparative Education, Taylor and Francis, Routledge, 2010, p. 524, accessed online on 7 March 2015; $<$ http://www.scribd.com/doc/208124384/Halstead-An-Islamic-Concept-ofEducation\#scribd>

16. The "Law and Literature Movement" emerged in the US in response to the 
"nihilist postmodernism epitomized by the Critical Legal Studies movement," which had a tendency to conceive of the domain of the ethical as something separate from the legal. According to the LLM, the severed link between ethics and law can be re-established by teaching literature, as literature is inherently ethical. See Ward, Ian "From Literature to Ethics: The Strategies and Ambitions of Law and Literature," Oxford Journal of Legal Studies, Vol. 14, No. 3 (Autumn, 1994), Oxford University Press, pp. 389-400, accessed online on 25 Feb. 2015; $<$ http://proxy.aju.edu:2254/stable/pdf/10.2307/764737.pdf?acceptTC=true>

17. Durrani, Haris A. "Literature and Agency in Islamic Discourse," University of Toronto Undergraduate Journal of Middle East Studies, Issue 8, 2014-2015, Toronto, p. 6, accessed online on 27 March 2015; <http://nmc.utoronto.ca/wpcontent/uploads/2014/03/NMCSU-Journal_2015_protected.pdf>

18. C.f. Qur'an 5:100. In other words, good literature should give the lie to the popular but false dictum, according to which "nice guys finish last." Barazangi, Nimat Hafez, Donald Malcolm Reid, Syed Rizwan Zamir, Dietrich Reetz, Joseph S. Szyliowicz, Akbar S. Ahmed and Anis Ahmad, "Education," in Oxford Islamic Studies Online, accessed online on 21 February 2015; <http://www. oxfordislamicstudies.com/article/opr/t236/e0212

19. Early (pre-modern) revivalist thinkers included notably imam al Ghazali (d. 1111). See Jörn Thielmann's review of John Esposito's Islam and Politics, Journal of Law and Religion, Vol. 15, No. 1/2, 2000 - 2001, pp. 615-619, accessed online on 29 March 2015; <http://www.jstor.org/stable/1051578>

20. Kamali, Hashim Principles of Islamic Jurisprudence, Ilmiah Publishers, 2004, pp. 38-39.

21. "Qur'an," in Oxford Islamic Studies Online, accessed online on 21 February 2015; < http://www.oxfordislamicstudies.com/article/opr/t243/e275> See also Omran, Elsayed M.H, "Islam, the Qur'an and the Arabic Literature," Al-Serat A Journal of Islamic Studies, 1988 - miracleofquran.net, p. 10; accessed online on 15 February, 2015, <http://www.miracleofquran.net/resources/news/content/ $\mathrm{pdf} / 313 . \mathrm{pdf}>$

22. Omran, Elsayed M.H, "Islam, the Qur'an and the Arabic Literature," Al-Serat A Journal of Islamic Studies, 1988 - miracleofquran.net, p. 4; accessed online on 15 February, 2015, <http://www.miracleofquran.net/resources/news/content/ $\mathrm{pdf} / 313 . \mathrm{pdf}>$

23. For an alternative perspective on the story of Joseph, and its influence on the literature of pre-modern Spain, see Patterson, Charles P. A Fruitful Bough: The Old Testament Story of Joseph in Medieval and Golden Age Spanish Literature, Dissertation Presented to the Faculty of the Graduate School of The University of Texas at Austin, 2009, accessed online on 29 March 2015; <http://www.lib. utexas.edu/etd/d/2009/pattersonc11444/pattersonc11444.pdf>

24. Q ali-Imran, 3:54, Q al-Anfal, 8:30.

25. Tolstoy, Leo What is Art? What is Religion? RareBooksClub.com, 2012.

26. Mann, Thomas Joseph and His Brothers: The Stories of Jacob, Young Joseph, Joseph in Egypt, Joseph the Provider, Everyman's Library, 2005.

27. For the influence of Iqbal on contemporary Islamic thought in general, and literature in particular, see various essays in Iqbal Review, Journal of the Iqbal Academy, Pakistan, Muhammad Suheyl Umar (Ed.), Iqbal Cyber Library, 
October 1997, Vol. 38, no. 3, accessed online on 5 March 2015, <http://www. iqbalcyberlibrary.net/pdf/IRE-OCT-1997.pdf>

28. Dutton, Yasin "The Genesis of Literature in Islam: From the Aural to the Read," by Gregor Schoeler, revised edition in collaboration with and translated by Shawkat M. Toorawa, Journal of Islamic Studies, Volume 22, Issue 1 pp. 77 - 79, p. 77, accessed online on 7 March 2015, <http://jis.oxfordjournals.org/ content $/ 22 / 1 / 77>$

29. n.a. "Asabiyyah," Oxford Islamic Studies Online, accessed on 28 February 2015; $<$ http://www.oxfordislamicstudies.com/article/opr/t125/e202? hi=0\& pos=11>

30. n.a. The Islamic World, with an Introduction by Ziauddin Sardar, Running Press, Philadelphia and London, 2009, p. 312.

31. Sonn, Tamara A Brief History of Islam, Blackwell Publishing, 2004, p. 46.

32. Rumi, Jalal al din The Masnavi, Oxford University Press, 2008.

33. Nasr, Seyyed Hossein Nasr, Islamic Art and Spirituality, Golgonooza Press, 1987, p. 140.

34. A ghazal is a form of poetic expression. It consists of two lines that rhyme and a refrain (repeated line or lines).

35. n.a. The Islamic World, with an Introduction by Ziauddin Sardar, Running Press, Philadelphia and London, 2009, p. 326.

36. Ibid, p. 332.

37. He noted famously "You can tell whether a man is clever by his answers. You can tell whether a man is wise by his questions." Fusco, Esther "A Critical Need for $21^{\text {st }}$ Century Education," in Sylwester Robert and David Moursund, (eds.), Creating an Appropriate $21^{\text {st }}$ Century Education, Information Age Education (IAE), 2012, p. 77, accessed online on 25 March 2015, <http://i-a-e.org/ downloads/free-ebooks-by-dave-moursund/243-creating-an-appropriate-21stcentury-education-1/file.html\#page $=77>$

38. Mahfouz, Naguib "Let's Make the New World," first published in Al Ahram (Cairo, Egypt), August 26, 1993, reprinted in Dissent and Reform in the Arab World: Empowering Democrats, Jeffrey Azarva, Danielle Pletka, and Michael Rubin (eds.), The AEI Press, 2008, p. 119; accessed online on 25 March 2015; <http:// www.aei.org/wp-content/uploads/2009/01/20080304_DissentandReform.pdf $>$

39. Hassan, Riffat "Iqbal, Muhammad (1877-1938)" The Routledge Encyclopedia of Philosophy, University of Cambridge, Oliver Leaman (Ed.), Routledge, 1998 accessed online on 24 March 2015; <http://www.muslimphilosophy.com/ip/rep/ H037.htm\#H037SECT1>

40. Dickens, Charles Oliver Twist, Oxford University Press, 2008.

41. Charles Dickens' The Tale of Two Cities similarly takes place during the time of the French Revolution.

42. Hugo, Victor Les Miserables, G Books, 2011.

43. Tolstoy, Leo Anna Karenina, Oxford University Press, 2008.

44. Dante, The Divine Comedy, Oxford University Press, 2008.

45. The fact that literature written by non-Muslims may contain elements not in harmony with the Qur'anic worldview need not mean that therefore such literature should be in principle avoided. Weaknesses if any can be highlighted during the process of the literary analysis of the work. 